\title{
Demographic determinant of primary school repeater in Indonesia
}

\author{
Omas Bulan Samosir ${ }^{1, *}$ \\ ${ }^{1}$ Universitas Indonesia, Jakarta, Indonesia
}

\begin{abstract}
The development of a country is supported by its education development. In general, education is financed by the government. It is expected that all school-age population can participate in education. Indonesia has implemented the nine-year compulsory basic education program. The aim of this study is to examine the demographic factors that affect the primary school repeater in Indonesia. The data source was from the World Bank Development Indicator of the World Bank. The data coverage was from 1971 to 2018. The dependent variable was the primary school repeater rate. The independent variables were the population growth rate and fixed telephone subscription. The data were analyzed using multiple regression analysis. The results of the study indicate that higher primary school repeater was associated with higher population growth rate and lower fixed telephone subscription. Therefore, Indonesia needs to manage its population growth rate and improve infrastructure development, in particular information technology infrastructure.
\end{abstract}

\section{Introduction}

The development in education has had great impact on economic growth and human welfare, demographic dividend, and competitiveness of a country $[1,2,3,4,5,6]$. Education has provided the foundation for the new knowledge and resulted in needed advancement for sustained growth. Labor force training and education has made possible that technology is used in economic production. In addition, the life expectancy and health of the population is improving. The improved life expectancy has contributed to more than double to the productivity of the population in almost all developed countries [4,7]. Further, after physical development, the better quality of labor force is the economic growth chief driver.

In 2015, the United Nations (UN) set 17 sustainable development goals (SDGs) as the blueprint to achieve the better future and sustainability for everyone. The fourth goal of SDGs is to guarantee inclusive and equitable education for all [8]. The 2030 education framework provides guidelines to implement this ambitious goal and commitment [9]. [10] reported that there has been a great achievement in the universal basic education target. The total enrollment rate in developing region achieved $91 \%$ in 2015 and the dropout rate declined more than half. In addition, the literacy rate has increased significantly and more women participate in schooling more than before.

\footnotetext{
* Corresponding author: omasbr@yahoo.co.uk
} 
However, it is also understood that the progress in education development is still difficult in some developing regions due to high poverty, weapon conflict, and other emergency situations. In the western part of Asia and North Africa, weapon conflict had caused a number of students who dropout from school increased. The greatest achievement among all developing countries occurred in Sub-Saharan Africa where the primary school enrollment increased from $52 \%$ in 1990 to $78 \%$ in 2012 . There is still a great disparity. Children from the poorest households had dropout rate four times much higher than children from the richest households. The inequality between urban and rural areas is also still wide.

The impact of both formal and nonformal education on economic growth has been a wide study subject. A number of models and approaches were also carried out to study this association [11]. Reza \&Widodo [12] conducted an analysis of the relationship between education and population growth in Indonesia. They used a panel estimation method and found that an increase of $1 \%$ in average education per worker was associated with an increase of $1.56 \%$ in output.

There are a number of reasons why education is important as the determinant of economic growth (Grant 2017). Education can be defined as the stock of knowledge, skill, competence, and other productivity augmenting features. In general, education improves the efficiency of each worker individual and hence helps economy moves up. In addition, human capital has been long acknowledged as the most unique characteristic of economic system.

Education has positive impact on productivity growth. The more educated someone the better the prospect of the person to have better income through working sector in the future. In addition, education augments enablement and independence in main life aspects, such as capability for community participation, health care decision making, freedom to select spouse in marriage, and to improve welfare through income improvement and even capitalization of the demographic dividend $[13,6]$.

[14] proposed the role of education in fostering economic growth. They argued that there is a strong evidence that cognitive skill of population, not only school achievement, relates strongly with long-term economic growth.

[15] explained three channels how education affects productivity of a country. Firstly, education improves collective capability of labor force to carry out their tasks faster. Secondly, education facilitates knowledge and new information, product, and technology transfer. These three transfers create one another. Thirdly, augment creativity advanced the capacity of a country to create new knowledge, product, and technology [16].

To achieve inclusive and quality ducation for all strengthens the belief that education is a means of achieving the SDGs [10]. Therefore, it is also important to consider the school repetition and dropout rate and other distractions so they can be prevented.School repetition is ineffective and inefficient in term of academic and socio-emotional development of student. Repeaters are more likely to dropout earlier and can end with behavior problem.

School grade repetition occurs when a student starts a new class in the same grade with the grade in the previous academic year and does not move to higher grade [17]. Grade repetition indicates inefficiency and waste of community resources. From public economic point of view, investment in education and schooling is very effective if each student can attain the higher grade every year. Each grade repeater has impact on economy. If there are many grade repeaters every year, school systems will need more teachers and classes. Grade repeaters also reflect resources waste. Society provides schools, teachers, and other resources so the students can attain the expected achievement. Failure such as grade repetition wastes and is resource inefficiency and some students fail to obtain the benefit and opportunity provided. In addition, grade repetition impairs economic growth $[18,19,20]$. 
The relationship between demographic factors and education achievement has been addressed $[21,22,8,18,23]$. It was argued that population growth had an adverse impact on education received by children. Rapid population growth hindersthe development of education either by lessening the quality of education to sustain enrollment or by decreasing the quantity to retain the quality of education. This argument was supported by the study by [22] who found that fertility level had a negative impact on secondary school enrollment rates in less developing countries.

In Figure 1 the trend of school repeater in the world, by demographic dividend typology, and in Indonesia during 1988-2018 is given. It can be seen that the world repeater declined significantly. However, it varied greatly by demographic dividend typology. The repeater was consistently highest in pre-demographic dividend countries which implies high population growth countries and lowest in post-demographic dividend countrywhich implies low population growth countries. Meanwhile, during 1988-2002 repeater was quite high in Indonesia, even much higher than the world's repeater. It was only lower than the repeater in pre-demographic dividend countries. However, after 2002, Indonesia's repeater declined sharply and became lower than the world's repeater and also lower than repeater in pre- and early-demographic dividend countries. This achievement can be contributed to the concerted education program, in particular the nine-year compulsory basic education program.

Education achievement can also be influenced by the availability of infrastructure that reflects the development of a region. Regions with better infrastructure, including fixed telephone lines, are usually more developed and hence have better education facilities (Becta 2007). The availability of fixed telephone helps the promotion of education and improve access to education information to maintain the smoothness of schooling. In addition, information technology provided a number of new opportunities in education institution, provides new learning opportunity, including those that cannot be provided by formal education that in turn will lower the chance to have school grade repeaters.

Gómez-García et al. [24] carried out a research using data from the Ministry of Education in Spain in 2017. The number of students was 1,887,027 from 7,381 compulsory secondary education schools were analyzed about the impacts of mobile phone use on a number of education variables. Among them was repeater. Their study found that the number of repeaters declined as mobile phone use increased. Mobile phone use explained $53 \%$ of variation in the number of repeaters. When mobile phone use rate was below $26 \%$ of total population, the repeater rate was $11.8 \%$. When mobile phone use rate was above $26 \%$ of total population, the repeater rate became $8.2 \%$. This study shows the positive effect of information technology, in particular telephone on student's achievement, especially for students with low academic performance, to reduce the grade repetition rate and school failure percentage. 


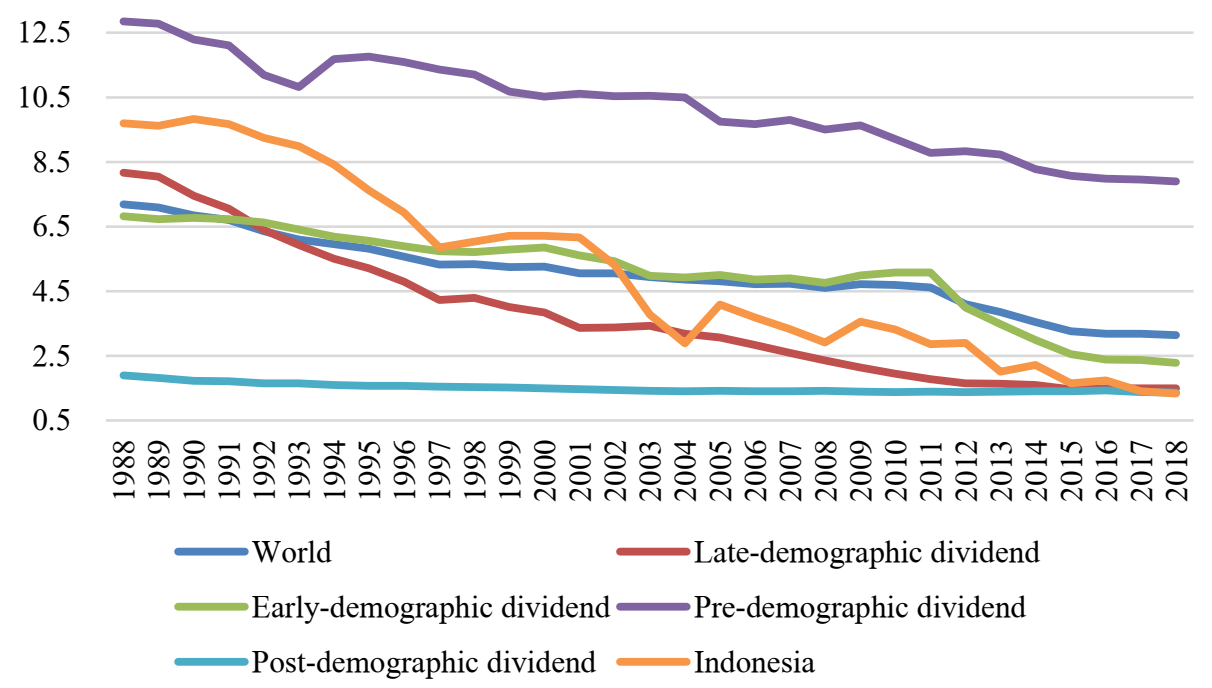

Fig. 1. Repeater (\%): World, by demographic dividend typology, and Indonesia 1988-2018 (Source: World Bank (2021)(Author's compilation).

Studies on the impacts of population growth and availability of fixed telephone on school grade repeater in Indonesia are limited. Therefore, this study aims to examine the association between population growth rate and fixed telephone subscription with primary school repeater in Indonesia.

\section{Data and Method of Analysis}

\subsection{Data}

The source of data in this study was from the World Bank Development Indicator for Indonesia of the World Bank (accessed January 25, 2021). The time coverage was from 1971 to 2018 . The dependent variable was the percentage of primary school repeatersoftotal of total enrollment. The independent variables included the annual population growth rate (\%) and fixed telephone subscriptions (per 100 people). Repeaters in primary school were enrolled students at the same grade as in the previous year as a percentage of all enrolled primary school students. Meanwhile, the fixed telephone subscriptions (per 100 people) referred to the number of active fixed telephone connection.

\subsection{Method of Analysis}

The univariate, bivariate, and multivariate data analyses were employed in this study. The summary statistics of variables in the study were produced for univariate analysis. The scatter diagrams between independent variables and dependent variable in the study were provided for bivariate analysis. A multiple regression analysis was carried out to study the association between the population growth rate and fixed telephone subscriptions and the percentage of primary school repeaters. 


\section{Results}

The results of univariate analysis are presented in Table 1 . These include the number of observations (n), minimum, maximum, mean, and standard deviation. It can be seen that the number of fixed telephone subscriptions per 100 people in Indonesia during 1971-2018 ranged from 0.13 to 16.93 . Meanwhile, the annual population growth rate differed from $1.134 \%$ to $2.654 \%$. Further, the primary school repeater varied between $1.3 \%$ and $12.0 \%$.

Table 1. Summary statistics of variables in the analysis: Indonesia 1971-2018 (Source: World Bank (2021), author's compilation).

\begin{tabular}{|l|c|c|c|c|c|}
\hline & $\mathbf{n}$ & Minimum & Maximum & Mean & $\begin{array}{c}\text { Standard } \\
\text { deviation }\end{array}$ \\
\hline $\begin{array}{l}\text { Fixed telephone subscriptions (per } \\
\text { 100 people) }\end{array}$ & 48 & 0.125 & 16.925 & 3.646 & 4.803 \\
\hline $\begin{array}{l}\text { Population growth (annual \%) } \\
\text { Repeaters, primary, total (\% of total } \\
\text { enrollment) }\end{array}$ & 48 & 1.134 & 2.654 & 1.764 & 0.492 \\
\hline
\end{tabular}

The results of bivariate analysis are displayed in Figure 2 and 3. It can be seen from Figure 3 that there was a positive correlation between the population growth rate and the percentage of primary school repeater in Indonesia. It means the higher the population growth rate the higher the percentage of primary school repeater. In addition, an increase of $1 \%$ in population growth rate was associated with an increase of $6.2 \%$ in the percentage of primary school repeater.

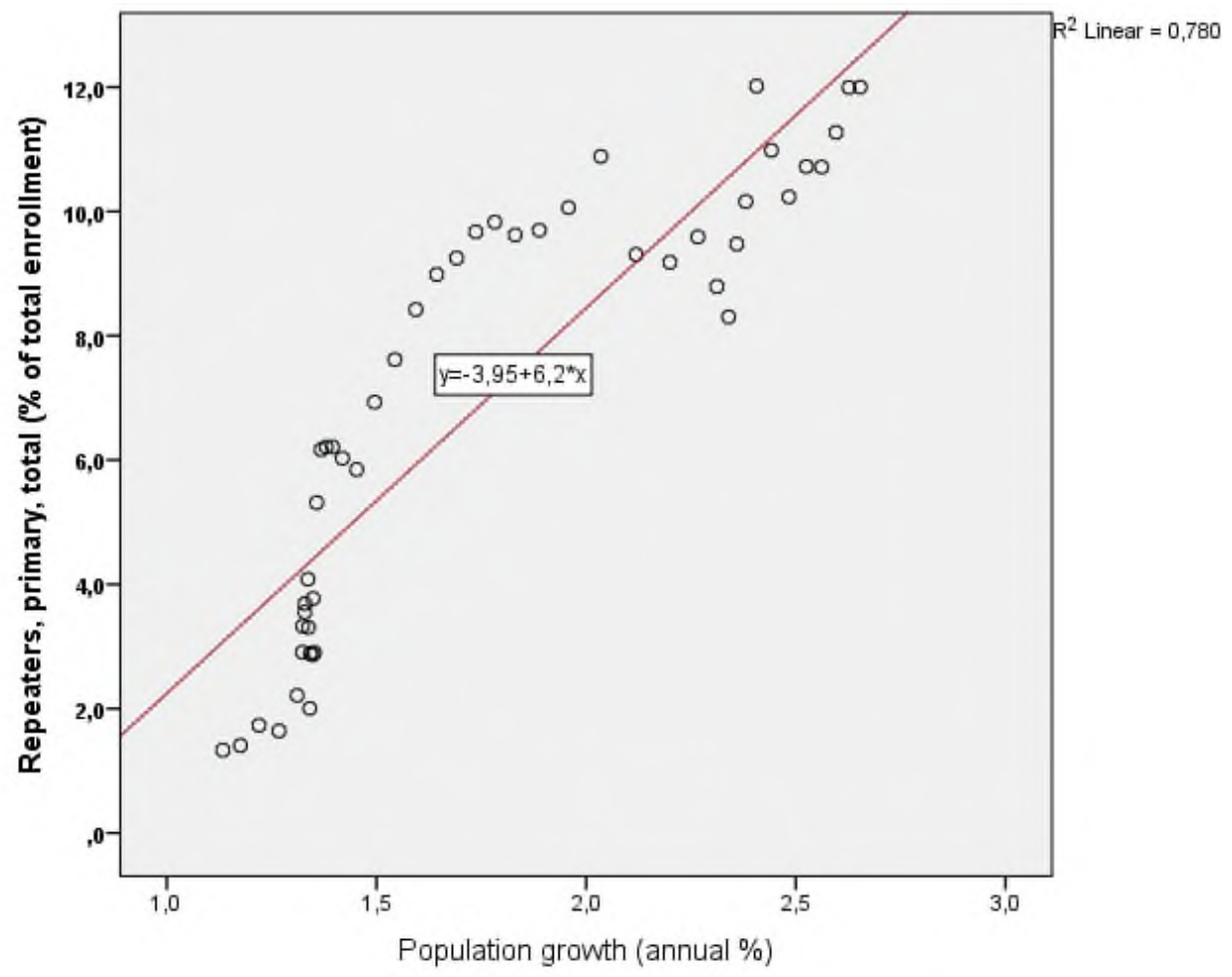

Fig. 2. Population growth rate (\%) and primary school repeaters (\%): Indonesia 1971-2018 (Source: [25] Author's compilation). 
Figure 4 shows that there was a negative relationship between the fixed telephone subscriptions and the percentage of primary school repeater in Indonesia. It means the higher the number of fixed telephone subscriptions per 100 people the higher the percentage of primary school repeater. In addition, an increase of 1 in the number of fixed telephone subscriptions per 100 people was related with a decrease of $0.54 \%$ in the percentage of primary school repeater [26].

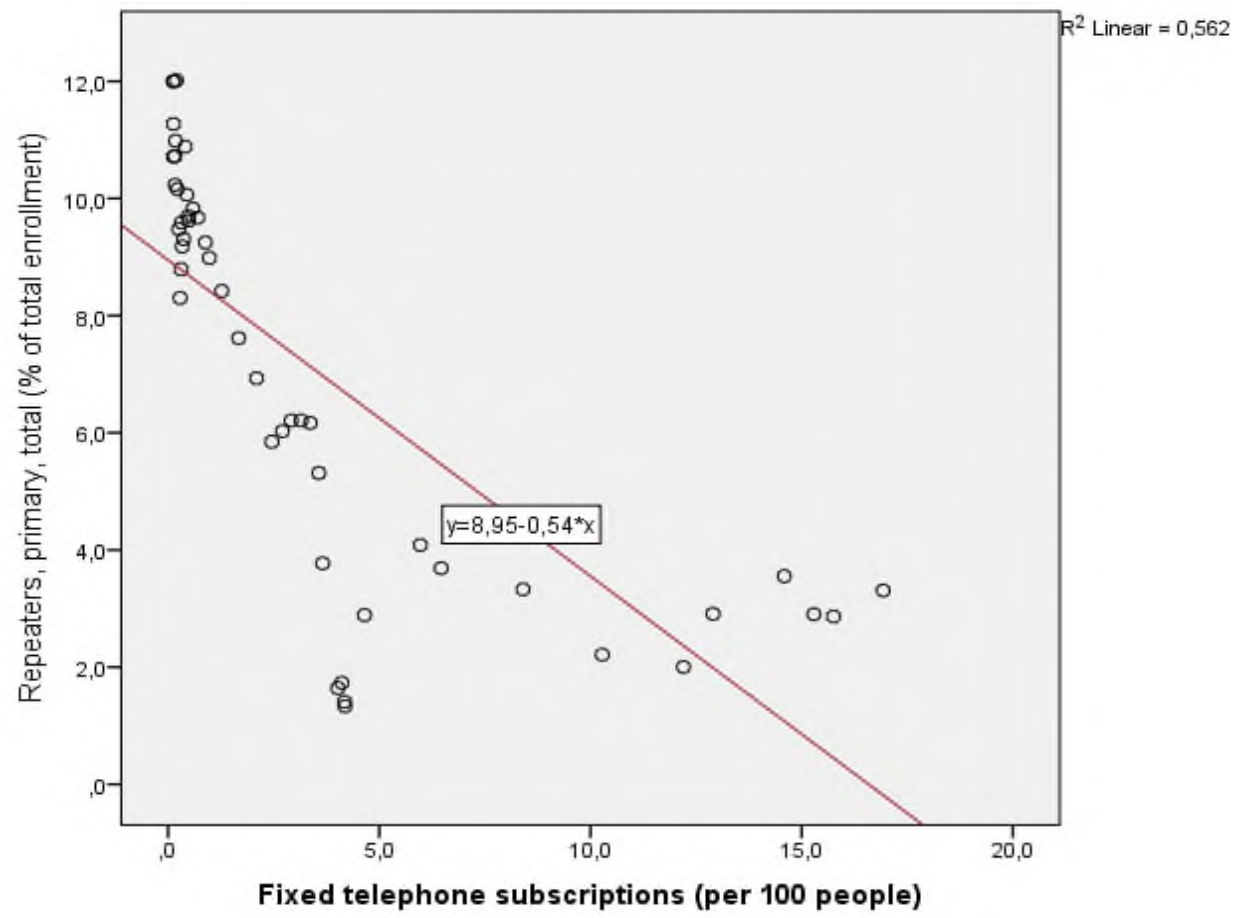

Fig. 3. Fixed telephone subscription (per 100 people) and primary school repeaters (\%): Indonesia 1971-2018 (Source: [25], Author's compilation).

The results of multivariate analysis are given in Table 2. These include the coefficients, standard error, $t$, and signigicance of multiple regression model of the determinants of primary school repeater. It can be seen that population growth rate and number offixed telephone subscriptionare statistically and significantly associated with primary school repeaters in Indonesia during 1971-2018.

Population growth rate is positively associated with primary school repeater and significant at the less than 0.001 significance level. Other things being the same, on average, an increase of one percent in population growth will increase primary school repeater by $4.8 \%$. In this study, Population growth rate was the strongest factor of primary school repeater [27].

Fixed telephone subscriptionis negatively associated with primary school repeater and significant at the less than 0.001 significance level. After controlling for the effects of other factor, on average, an increase of one percent in fixed telephone subscriptionwill reduceprimary school repeater by $0.233 \%$. In this study, fixed telephone subscriptionwas the second strongest factor of primary school repeater. 
Table 2. Coefficients, standard error, $t$, and signigicance of multiple regression model of the determinants of primary school repeater: Indonesia 1971-2018 (Source: [25] Author's compilation).

\begin{tabular}{|c|c|c|c|c|}
\hline Variables & Coefficients & $\begin{array}{c}\text { Standard } \\
\text { error }\end{array}$ & $\mathbf{t}$ & Significance \\
\hline Constant & -0.595 & 1.093 & $\begin{array}{c}- \\
0.544\end{array}$ & 0.589 \\
\hline Population growth (annual \%) & 4.777 & 0.532 & 8.980 & $<0.001$ \\
\hline $\begin{array}{l}\text { Fixed telephone subscriptions (per } \\
100 \text { people) }\end{array}$ & $-0,233$ & 0.055 & $-\overline{2}$ & $<0.001$ \\
\hline
\end{tabular}

\section{Conclusions}

The results of this study indicate that Indonesia experienced improvement in its education achievement during 1988-2018: the percentage of primary school repeaters. The findings from this study also suggests that a higher population growth rate can lead to a larger number of school-age population and with limited education facilities and investment, in particular competent teachers, might cause a larger number of repeaters in Indonesia.

Higher population growth rate can also cause higher malnutrition among school-age population that can lead to lower cognitive skills and abilities and as a consequence higher chance of repeating. In addition, as a measure of better development, higher number of fixed telephone subscriptions can lead to better primary school education achievement and hence result in lower repeaters.

Therefore, in order to reduce primary school repeaters Indonesia should improve its population development through population growth management and improvement in access to information and communication technology. For further study, the impacts of repeater on economic growth and other economic indicators should be investigated.

\section{References:}

1. R.J. Barro, J.-W. Lee, A New Dataset of Educational Attainment in the World, 19502010 NBER Working Paper No. 15902 (Cambridge, MA: National Bureau of Economic Research, 2010)

2. D. Ushakov et al., Montenegrin J. of Economics 13(1), 171-179 (2017)

3. L. Wößmann, Education Economics 24 (2007)

4. R. Salle, Human capital and economic growth (Cambridge University Press, 2010)

5. O.B. Samosir, W. Rajagukguk, Regional Competitiveness and National Economic Growth (2017) https://doi.org/10.4018/978-1-5225-3856-1.ch016
6. W.
Rajagukguk,
E3S
Web
of
Conferences
https://doi.org/10.1051/e3sconf/202017513035

7. O. Patlasov et al, The EUrASEANs: J. on Global Socio-Economic Dynamics 1(20), 69-87 (2020)

8. United Nations, Population, Education and Development (Department of Economic and Social Affairs Population Division, 2003)

9. S.K. Chattaraj, Int. J. Trend Sci. Res. Dev. (2017) https://doi.org/10.31142/ijtsrd5889

10. United Nations, Transforming Our World: The 2030 Agenda For Sustainable Development (United Nations Dev. Program, 2016)

11. D.W. Cheek et al., International Encyclopedia of the Social \& Behavioral Sciences: Second Edition (2015) https://doi.org/10.1016/B978-0-08-097086-8.92058-0 
12. F. Reza, T. Widodo, J. of Indonesian Economy and Business 28(1) (2013)

13. M.P. Todaro, S.C. Smith, Economic Development (Pearson, 2015)

14. E.A. Hanushek, L. Wößmann, Intern. Encyclopedia of Education (Elsevier, Oxford, 2010)

15. Global Competitiveness Report 2015-2016 (World Economic Forum, 2016)

16. H. Mai et al., Intern. J. of Recent Technology and Engineering 8(2.11), 3876-3882 (2019)

17. J. Brophy, Education Policy Series 6 (2006)

18. Agasisti et al., The determinants of repetition rates in European countries:insights from an empirical analysis using PIRLS 2011 data (2011) https://www.educacionyfp.gob.es/inee/dam/jcr:41 ea4236-0eb6-46dc-86c8431162cd150d/paper--repetition-europe.pdf

19. E. Rievajová et al., The EUrASEANs: J. on Global Socio-Economic Dynamics 5(18), 55-64 (2019)

20. S. Ferraro et al., Local governments' efficiency and educational results: empirical evidence from Italian primary schools (MPRA Paper, University Library of Munich, Germany, 2020)

21. T.N. Chau, Population growth and costs of education in developing countries (United Nations Educational, Scientific and Cultural Organization, 1972)

22. M.M. Ihnatenko et al., Intern. J. of Economics and Business Administration 7(2), 290301 (2019)

23. S. Mayhew, T. Colbourn, Population growth. Thinking Beyond Sectors for Sustainable Development (Ubiquity Press, London, 2015)

24. M. Gómez-García et al., Using Mobile Devices for Educational Purposes in Compulsory Secondary Education to Improve Student's Learning Achievements, Sustainability (2020) doi:10.3390/su12093724

25. Word Bank, World Bank Open Data (2021) https://data.worldbank.org/

26. A.H. Tran et al., Intern. J. of Recent Technology and Engineering 8(2.11), 3883-3888 (2019)

27. C. Grant, The contribution of education to economic growth (The K4D helpdesk, 2017) 